\title{
Stem Cell Differentiation
}

National Cancer Institute

\section{Source}

National Cancer Institute. Stem Cell Differentiation. NCI Thesaurus. Code C19045.

Differentiation of stem cells into specialized cells 